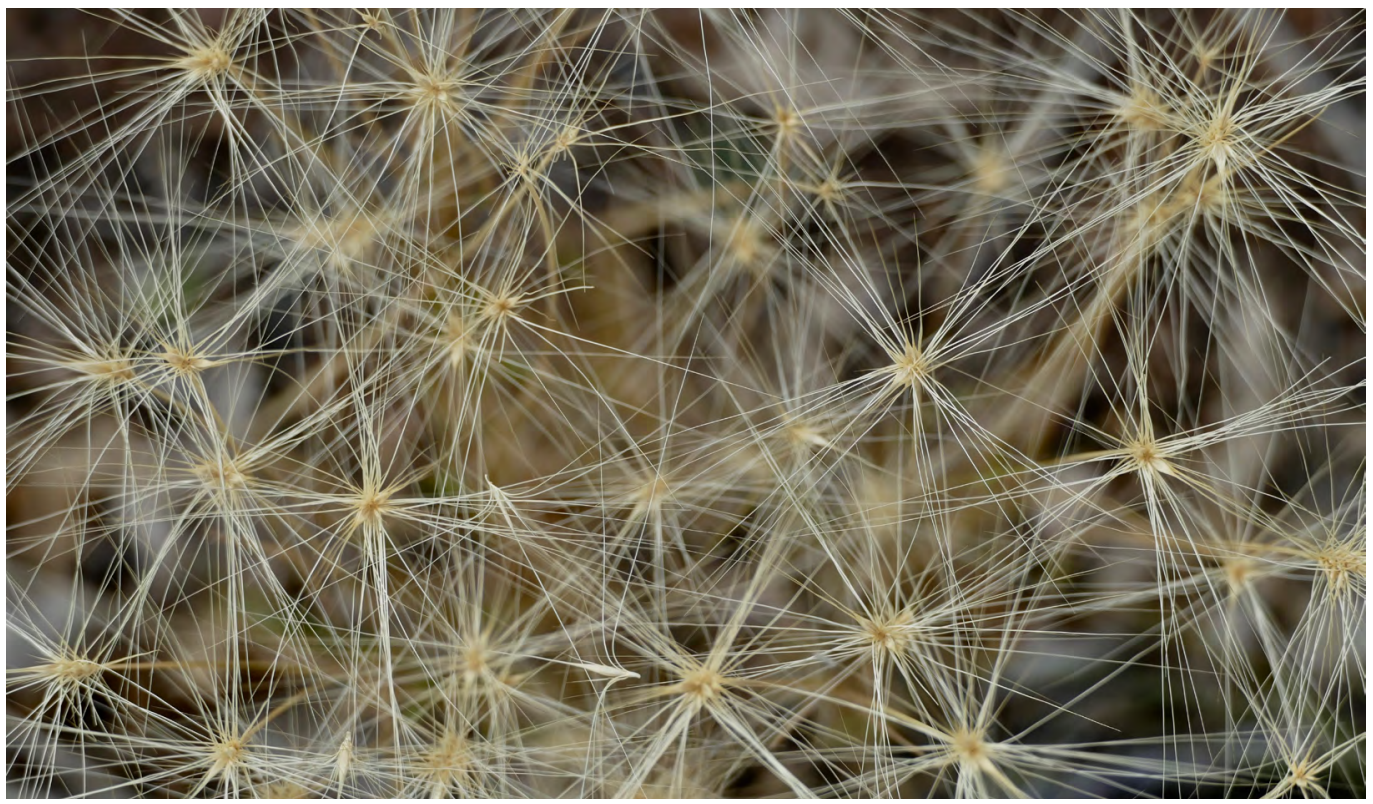

\section{Chinese Diaspora Activism and the Future of International Solidarity}

Mengyang ZHAO

Diaspora activism is frequently perceived as limited to activists' involvement in topics directly related to their homelands, which are often non-democracies with repressive systems. This essay argues that this perception snatches away the agency of diaspora populations, and curbs our ability to imagine the breadth and depth of transnational activism that is taking place today.
Interconncections. PC: Art by Bart, 2019.
Y asmin is an international student residing in a southern US city. A queer activist back in China, she participates in the graduate union campaign in her university and is also a community organiser. She is among a group in the Chinese diaspora who are involved in country-ofresidence social movements, a reality that tends to be overlooked in the landscape of contemporary social movements.

Diaspora activism occupies a strange position in today's social movements. It is at least a century-old phenomenon, with radical 
anarchists and communists transgressing national boundaries to breed revolutions during the early twentieth century being the most notable example (Anderson 2013). The history of Chinese diaspora activism could also date back to the late Qing dynasty, when the diaspora established multiple revolutionary groups overseas (Lai 2010). However, both narratives and practices of diaspora activism underwent a gradual conservative turn with the strengthening of national borders, the end of the Cold War, and the formalisation of social movement theories during the last century that are often strictly confined to national contexts.

Nowadays, stemming from Hirschman's (1978) famous 'exit and voice' framework, public memories of diaspora activism are conspicuously reduced to activists' involvement in topics directly corresponding to their homelands, which are usually nondemocracies with a repressive system (Quinsaat 2013). However, based on my study of Chinese diaspora activism, I argue that such an essentialist tendency frames social movements in non-democracies as antithetical to those in democracies, trivialising the potential interaction and mutual learning between the two fields. Not only does it risk snatching away the agency of diaspora populations, but it also curbs our ability to imagine the breadth and depth of transnational activism that is taking place in today's multi-layered political sphere.

\section{The Case of Chinese Diaspora Activists}

While mobilising for homeland politics constitutes an important and irreplaceable dimension for diasporic communities, it is by no means the only realm and mode of political participation. Diaspora politics also irrevocably intersects with social justice topics in the country of residence, as there are never clearcut boundaries between the two issues. Even mobilisation solely for homeland politics often involves the collaboration with country-of- residence social organisations. Problematising previously narrow presumptions of diaspora is therefore essential, since the processes through which diaspora activists interact with local social movements could not only bring new thoughts and praxes to country-of-residence activism, but also impact activists' subsequent engagement with homeland politics.

From early 2017 to late 2019, I conducted participatory observation of several Chinese diaspora activist communities and conducted repeated interviews with diaspora and nondiaspora activists residing in the United States, Europe, and China. While I chose to concentrate on the Chinese case due to my positionality as a former student activist, more importantly, Chinese diaspora activists are an exemplary case for exposing the problems and contradictions involved in transnational social movement participation.

In the media spotlight, members of the Chinese diaspora are conveniently portrayed as either dissidents against an Orwellian state or loyal trumpeters for a totalitarian government, with both approaches implicitly assuming them to be victims, even though the former is framed in a much more positive light. Such reduction of-or total blindness toward-the agency of those in the diaspora renders its diverse and evolving modes of political participation invisible. The ways in which those in Chinese diasporic communities politically engage are viewed as incongruent with the modes of political participation in liberal democracies, leading many to overlook their potential contributions to social movements in democracies, both intellectually and practically.

Patterns of diaspora activism are embedded in larger historical forces that shape the ebbs and flows of resistance. Since the 1980s, older activist generations have been more likely to be trapped in the dualism of authoritarian versus democracy and to build a closer relationship with political elites in democracies, while younger cohorts have been able to forge stronger ties with progressive social movements in the societies of residence, and 
also have a more critical take on neoliberalism. In fact, nowadays almost all young Chinese activists with a history of involvement in NGOs or more radical actions back home are also keen participants in progressive social movements in their countries of residence, as they tend to have a general fervour for promoting social justice universally, and also have developed transferable expertise via their organising work in China that allows them to navigate the social movement field in a relatively smooth way. Some even play key roles in local movements despite initial difficulties in integrating into the community.

At the same time, it is important to not forget the evolving dynamics of contentious politics in the countries where activists reside. The rise of populist rightist groups in global politics has also contributed to the resurgence of progressive social movements everywhere. The increased visibility of protests inevitably draws many in the diaspora into social movements. For instance, in my study, three activists mentioned Trump's election back in 2016 and the ensuing protests as a crucial period when they palpably felt a strong sense of urgency for direct action. It is in such moments of crisis that diaspora activists earnestly thrust themselves into country-of-residence politics.

\section{Transnational Engagement and Meanings of Resistance}

\footnotetext{
How do Chinese diaspora activists' brave forays into country-of-residence social movements inform and enrich our understandings of social movement transnationalism and global solidarity? Based on my interactions with activists, it is precisely their criticism of, and reflections on, social movements in democracies that have the potential to deepen the meanings and subsequent practice of their resistance.
}

Many activists are disheartened by the fact that social movements in democracies fail to possess the transformative vision they used to imagine before migration. A sneak peek at the languages they use to describe Western social movements reveals the disenchantment. To them, social movements in their host countries are 'formal', 'playful', 'non-confrontational', a 'carnival', 'commercial', and 'bureaucratic', lacking a sense of political urgency to push for real social change. Activists are also quick to discover the mismatch between social movement narratives and practices, as many radical discourses fail to be transformed into concrete and sustainable actions.

Part of the disenchantment results from the divergent contexts of social movements in China and liberal democracies. In China, since openly collective actions are severely restricted, many NGOs have taken up the role of movement coordinators, organising campaigns in a way parallel to social movement organisations in democracies (Pringle 2018). Chinese NGOs also hire members with activist personalities who sometimes organise actions outside of the bounds of normal organisational practice. Such fusion and ambiguity of roles are seldom the case in democracies, where functional boundaries are more clearly set for different social organisations. One unnamed informant even told me her NGO officially forbids its employees from engaging in organised rallies and marches, let alone spontaneous protests.

While activists acknowledge there are highly confrontational and disruptive social movements in liberal democracies, especially those organised by racial minorities and anti-capitalist activists, the general level of movement contentiousness and urgency they encounter pales in comparison with that of China. Back home, many activists fight tooth and nail and are forced to come up with creative strategies every time they organise campaigns around issues such as labour rights, feminism, and the environment, and the best ways to deal with authorities also keep changing. Many 
face illegal harassment and interrogation, eviction from rented houses and confiscation of personal belongings, and some have had experiences of being detained. Paradoxically, a repressive and ever-changing political climate in China produces both intense anxiety and high efficacy as activists feel they are doing transformative activism, while a safer environment in the West makes activism feel more like a set of mundane activities.

These criticisms by diaspora activists are not new to activists and scholars in democracies who live through similar frustrations within movements, especially when they risk reproducing the existing class, race, and gender hierarchies via ostensibly social justice work. The unique positionality of diaspora activists, however, is related to their organising experiences back home, which render them more sensitive to differences in organising models and difficulties of building solidarity. Their comparative insights thus serve as bridges between movements under different political contexts. One activist even mentioned she was able to apply the organising strategies that she had learned back in China to union campaigns in her residence city.

\section{Negative Movement Learning and Disenchantment toward International Solidarity}

Social movement theories have long proposed that commonalities between localities facilitate the diffusion and transfer of social movement knowledge. Yet, stories of Chinese diaspora activists divulge an alternative learning process that I refer to as 'negative learning', as problems of, and differences between, social movements they have observed can also serve as intellectual resources for future actions. Despite expressing sharp criticisms and doubts, activists pointed to many elements they have learned from country-of-residence movements, including both tactical knowledge of organising and, more fundamentally, comparative and intersectional perspectives on resistance and social change. For example, labour union bureaucratisation prompts some to rethink the issue of workers' spontaneity, while internal racism within social movements motivates others to introduce black feminism to a Chinese audience. Such negative learning constitutes a vital process through which movements from different political contexts enrich each other.

Simultaneously, however, direct participation in activism in the country of residence results in the painful realisation by many diaspora activists that social movements in democracies are much more parochial than they previously imagined. The vast majority of social movements are not organised in a way that recognises and cherishes the knowledge of diaspora. As one activist recalled, after joining a radical organisation, he was simply viewed as another newbie who could provide free labour for the activist group. Activists also discover that movement organisations rarely show genuine support for struggles outside of the United States or Europe. One labour activist lamented the lack of a global justice perspective in labour unions, and complained that people who share such sentiments are often marginalised. Even if solidarity is included in a movement's slogan, according to some interviewees, it is merely a rhetorical or symbolic strategy aimed at gaining moral legitimacy, rather than entailing concrete processes aimed at reinforcing forms of joint resistance.

Reckoning with this disappointing reality, some activists start to feel a stronger identification with social movements in China and no longer see themselves as transnational activists. This is not an outright rejection of the value of transnationalism per se, but instead the outcome of a more pessimistic take on the potentials for global solidarity than the often romanticised and tokenised depictions portrayed in the media and within activist communities. In the long run, it is possible that activists will overcome this pessimism and exert 
even more effort in fostering transnationalism despite the unfavourable reality, but at least in the short run this disenchantment could lead to movement burnout and should be taken seriously.

This also implies that the romanticising of global solidarity could backfire once diaspora activists are directly engaged in the convoluted country-of-residence social movements. My comparative analysis of diaspora and nondiaspora activists also shows that before migration, the majority of Chinese activists had no strong preexisting opinions of social movements in the West, as most of them only had limited exposure to social movements in other countries mediated via social media. If they did have preexisting opinions, the general impression tended to be positive. It is direct participation in country-of-residence political activism that reorients their attitudes and produces new activist subjectivities. As one activist reflected after moving back to China, overseas experiences have granted him a much more complicated understanding of social resistance in China and abroad, and it was quite 'liberating' to realise that Western social movements are not necessarily superior.

\section{Pandemic, BLM2020, and the Future of Diaspora Activism}

How can Chinese diasporic activism sustain and develop itself in the shadows of the current pandemic and the resurgence of right-wing nationalism? The increasingly aggressive immigration policies adopted by the US authorities exert a chilling effect on diaspora activists who could now face deportation for participation in protests and assemblies. Compared with native activists, diaspora activists suffer from the 'triple penalty' of simultaneously being activists, immigrants in their residence societies, and activists in their home country. In recent years, the Chinese state has aggressively tightened its grip on all forms of activism, and even diaspora activism might be placed under closer scrutiny under the expansion of transnational repression, especially after the passage of the Hong Kong National Security Law.

The worsening of the US-China relationship is taking another heavy toll on Chinese diaspora activists in the United States, as they are increasingly caught between two ruthless empires demanding loyalty from their own citizens. Not wanting to ally with either side, they have been put into a condition of emotional if not physical exile, with many US diaspora activists expressing deep anxiety over the crisis and their personal safety in both countries.

Starting in May 2020, the Black Lives Matter (BLM) protests have created some silver linings amid these dark times. As a decentralised movement, BLM provides new opportunity for Chinese diaspora activists to unite against racism and rework the meanings of transnationalism in their own way. Chinese diaspora activists have joined the nationwide protests in various cities, organised online forums, established reading groups, conducted public writings, and produced podcasts to divulge and reflect anti-Blackness within Asian communities ( $M a$ 2020). Their timely engagement might not change even a fraction of the whole picture in an era of heightened 'virus nationalism', but such efforts point to viable ways activists could still organise critical interventions in a divided world.

Therefore, it is even more imperative for both the academia and activist communities to interrogate and deconstruct the ideological and ethnic essentialism inherent in analyses of diaspora politics, making visible those efforts that challenge our parochial imagination of transnational social movements. Even social movements purposely mobilised in a local setting could have unintended global impacts, and it is these previously unarticulated transnational lessons that form the radical potential for future activism. 
This text is taken from Made in China Journal: Volume 5, Issue 2, 2020 , edited by Ivan Franceschini and Nicholas Loubere, published 2020 by ANU Press, The Australian National University, Canberra, Australia.

doi.org/10.22459/MIC.05.02.2020.09 